\title{
"Even love was not enough": Thinking about Attachment Paradigm Through Turkish Films
}

Application Date: 16.09 .2021

Accepted Date: 17.12 .2021

Publishing Date: 30.12 .2021

\author{
Gizem Parlayandemir ${ }^{1}$ \\ Istanbul University, Faculty of Communication, \\ Department of Radio, Television and Cinema, Istanbul \\ gizem.parlayandemir@istanbul.edu.tr \\ D) ORCID: 0000-0001-6652-2125
}

\begin{abstract}
The relationships are the subjects represented in the cinematic narratives. The relationship patterns of the characters in the film texts produce, reproduce, and promulgate the representation of gender conventions. The relationships between the characters in the film texts form the discourse that normalizes the individualism propagated, especially by the neoliberal paradigm and the absence of the labor required to repair human relations. They also allow thinking about our attachment patterns, which are our basic needs and conflicts simultaneously.
\end{abstract}

The attachment paradigm describes the behavioral approach focusing on attachment theory and models. Attachment patterns can vary depending on both stories and characters.

In this study, ten Turkish films were selected from a wide range of times between 1965 and 2020 and analyzed with discourse analysis to discuss the different attachment patterns and gender conventions. The popular films Vesikalı Yarim, Selvi Boylum Al Yazmalım, Issız Adam, and Biz Böyleyiz; and the independent films Sevmek Zamanı, Kader, and Körleşme are examples to discuss examples of avoidant, anxious, anxious-avoidant attachment. The popular films Mucize and Nadide Hayat are examples to question secure attachment from different perspectives. Gerçek Kesit: Manyak is chosen as an extreme example because it reveals the relationship between insecure attachment and the masculinity crisis with violence.

Anahtar Kelimeler: Attachment paradigm and cinema, attachment paradigm and Turkish films, Turkish films and gender representation.

\footnotetext{
${ }^{1}$ Associate Professor
} 


\title{
"Sevgi de yetmiyormuş": Türk Filmlerinde Bağlanma Paradigmasını Düşünmek
}

BaşvuruTarihi: 16.09.2021 Yayın Kabul Tarihi: 17.12 .2021 Yayınlanma Tarihi: 30.12 .2021

\author{
Gizem Parlayandemir ${ }^{2}$ \\ İstanbul Üniversitesi, Illetişim Fakültesi, \\ Radyo, Televizyon ve Sinema Bölümü, İstanbul \\ gizem.parlayandemir@istanbul.edu.tr \\ (iD) ORCID: 0000-0001-6652-2125
}

\section{öz}

ilişskiler, sinemasal anlatımlarda temsil edilen konulardandır. Film metinlerindeki karakterlerin ilişki kalıpları, toplumsal cinsiyet uzlaşımlarının temsilini üretir, yeniden üretir ve yayar. Film metinlerindeki karakterler arasındaki ilişkiler, özellikle neoliberal paradigmanın yaydığı bireyciliği ve insan ilişkilerini onarmak için gereken emeğin yokluğunu normalleştiren söylemi oluşturur. Aynı zamanda temel ihtiyaçlarımız ve çatışmalarımız olan bağlanma kalıplarımız hakkında düşünmeyi de sağlarlar.

Bağlanma paradigması, bağlanma teorisi ve modellerine odaklanan davranışsal yaklaşımı tanımlar. Bağlanma kalıpları hem hikayelere hem de karakterlere göre değişebilir.

Bu çalışmada, 1965-2020 yılları arasında geniş bir zaman aralığından seçilen on Türk filmi, farklı bağlanma kalıplarını ve cinsiyet uzlaşımlarını tartışmak için söylem analizi ile analiz edilmiştir. Popüler filmler Vesikalı Yarim, Selvi Boylum Al Yazmalım Issız Adam ve Biz Böyleyiz; ve bağımsız filmler Sevmek Zamanı, Kader, Körleşme kaçınan, kaygılı, kaygııl-kaçınan bağlanma örneklerini tartışıyor. Popüler filmler Mucize ve Nadide Hayat, güvenli bağlanmayı farklı açılardan sorgulamaya örnektir. Gerçek Kesit: Manyak, güvensiz bağlanma ile erkeklik krizinin şiddetle ilişkisini ortaya koyduğu için uç bir örnek olarak seçilmiştir.

Anahtar Sözcükler: Bağlanma paradigması ve sinema, bağlanma paradigması ve Türk filmleri, Türk filmleri ve toplumsal cinsiyet temsili.

\footnotetext{
${ }^{2}$ Doçent Doktor
} 


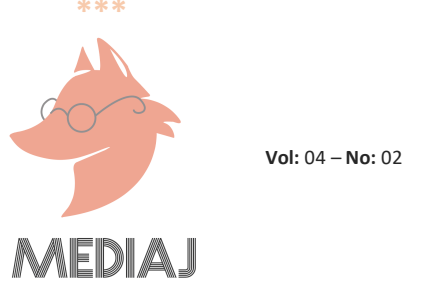

\section{INTRODUCTION}

Cinema, as the art of representation and communication, enables the spectator to understand the present reality, while as a product of the culture industry, it reproduces and reconstructs reality and puts it into the circulation of social consciousness and subconscious. The relationship is one of the subjects represented in the cinematic narratives.

Stuart Hall is one of the most critical thinkers in cultural studies whose works are essential to realizing the relationships between representation, meaning, and discourse. He states "three approaches to explaining how representation of meaning through language works" (Hall, 1997, p. 24) and names them as "the reflective", "the intentional" and "the constructionist or constructivist" approaches (Hall, 1997, p. 24-25). As he mentions, "meaning is thought to lie in the object, person, idea or event in the real world, and language functions like a mirror, to reflect the true meaning as it already exists in the world" in the reflective approach (Hall, 1997, p. 24), while the second approach, intentional approach, contradicts the first case. In this approach, "it is the speaker, the author, who imposes his or her unique meaning on the world through language. Words mean what the author intends they should mean" (Hall, 1997, p. 25). The constructionist or constructivist approach underlines the power of the relationship between language and society (Hall, 1997, p. 25):

The third approach recognizes this public, social character of language. It acknowledges that neither things in themselves nor the individual users of language can fix meaning in language. (...) Constructivists do not deny the existence of the material world. However, it is not the material world which conveys meaning: it is the language system or whatever system we are using to represent our concepts. It is social actors who use the conceptual systems of their culture and the linguistic and other representational systems to construct meaning, to make the world meaningful and to communicate about that world meaningfully to others.

Since the third approach focuses on symbols and the construction of the meaning, it gains its prior place in cultural studies and cinema studies (Hayward, 2001; Sedgwick, 2003, p. 225-226). The other important facts to be mentioned are misrepresentation and stereotyping when the representation comes to the fore.

With any representation approach taken into account, films tell us whether in what form society transforms into or in what form society wants to be transformed to. In both cases, the films affect, transform, create or raise awareness and help us to understand the transformation.

In The Pervert's Guide to Cinema (Fiennes, 2006), Zizek states, "Cinema is the ultimate pervert art. It does not give you what you desire - it tells you how to desire.". The desire is a complicated term, and it can be linked with the Lacanian terms objet petit a and jouissance when the case is cinematic analysis. However, the relationship between cinema and psychology is more longstanding than the Lacanian approach to cinema studies.

The first film theorist, Hugo Munsterberg, was a psychologist, and his work is based on psychology (Munsterberg, 2001). Psychology is of primary importance for the work of Metz, one 


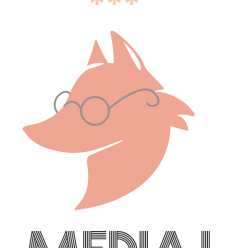

of the contemporary film theorists, psychoanalytic film theory, and the feminist film theory based on it (Hayward, 2001, p. 286-305). Psychological approaches and theories are also determinants for studies on public spectatorship experiences and the identification processes of the spectator (Hansen, 1994).

The relationship between psychology and cinema can guide thinking about different phenomena that interest people through film texts with information such as the influence of mirror neuron groups on the empathy process ${ }^{3}$ or Gerbner's work on media and violence (Gerbner, et. al, 1976). However, by watching films, we learn not only how to use violence or how to desire, but also how we love the other or establish bonds.

The characters' relationships in the film texts normalize the individualism propagated, especially by the neoliberal paradigm and the absence of the labor required to repair human relations. Moreover, they also allow thinking about our attachment patterns, which are our basic needs and conflicts at the same time.

Individualism as a lifestyle gains its important place with the neoliberal paradigm. Lewis (2011, p. 1145) states the "link between consumption and the notion of lifestyle choice as an expression of individualism came into its own in the 1980s, a period often seen as the peak of postmodern consumer culture" and according to her this culture "saw the emergence of a highly sophisticated media and advertising industry around life-style concerns alongside the rise of new market segments like the 'yuppie,' or young urban professional." Moreover, Lewis (2011, p. 1145) adds "Eighties-style neoliberal politics spoke in a language of free-market individualism which in turn dovetailed with postmodern consumer culture and its emphasis on flexible selfhood and the freedom to choose one's own lifestyle."

As Illouz states, in the context of close relationships, intimacy, like self-actualization and other categories invented by psychologists, became a code word for health. Healthy relationships were intimate, and intimacy was healthy. After the concept of intimacy was introduced as a rule and measure for healthy relationships, the lack of intimacy became the general framework that regulated the new therapeutic narrative of the ego. In this narrative, the lack of intimacy now pointed to a person's flawed emotional nature, such as fear of intimacy (Illouz, 2011, p. 73). The fear of intimacy can be read as a symptom of alienation. According to lllouz, the main reason why Marx's concept of alienation was adopted - and distorted - by popular culture was the emotional interests that could be achieved: modernity and capitalism were alienating because it created a kind of emotional numbness that cut people off from each other, from their society and their deep selves (IIlouz, 2011, p. 12).

\footnotetext{
3 Gruber (2004, p. 207) summarizes the development process for the studies on the subject mirror neuron groups in his work: "In 1992, cognitive neuroscientists working in Italy noticed neurons firing in the F5 motor area of a macaque monkey's brain, both when the monkey saw an action as well as when the monkey completed that same action (Di Pellegrino, Fadiga, Fogassi, Gallese, \& Rizzolatti, 1992). The name mirror neurons was subsequently given to those neurons that fired in both cases and was intended to suggest the idea that the monkey might be internally "mirroring" its visual environment through motor simulations. Since that time, mirror neurons have been studied extensively in relation to monkeys and humans, explored for their role in imitating movements (Caggiano et al., 2011; Carr, lacoboni, Dubeau, Mazziotta, \& Lenzi, 2003; Gallese \& Keysers, 2001); predicting other people's actions (Gallese \& Goldman, 1998; Umilta' et al., 2001; Goldman, 2006); identifying emotional expressions (Damasio, 2003; Gallese, Keysers, \&Rizzolatti, 2004; Wicker et al., 2003); and supporting complex memory systems (Gruber, 2002)."
} 


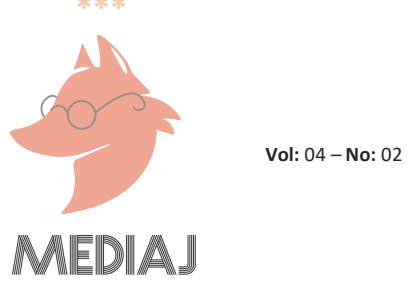

The discussion about alienation dates back to earlier times, and in the 1844 manuscripts of Marx states the layers of alienation and underlines the relationship between the economic structures and relations of production and the intrapersonal, interpersonal, and social relations (Marx, 1976).

The relationship patterns of the characters in the film texts also produce, reproduce and spread not only the economic relations but also the representation of gender conventions. While the researches, social policy regulations, and laws and rules such as Istanbul Convention underline the importance of the relationship between violence-free and gender-equal relations, and social conventions and perceptions (2011), hence media and representation gain an important effect on these social conventions and perceptions. The path to acts of violence is often paved with an insecure and unhealthy attachment paradigm.

The attachment paradigm describes the behavioral approach focusing on attachment theory and models. The attachment theory was founded by Bowlby in the 1950s, and the attachment models were founded by Ainsworth et al in the 1970s (Fraley \& Shaver, 2000). Attachment patterns can vary depending on both stories and characters. While anxious, avoidant, and anxious-avoidant attachment models differ, they may have commonalities in root causes (Levine \& Heller, 2018). It is possible to think that secure attachment can be learned later and transferred culturally.

There are external obstacles, especially in melodramatic narratives such as Vesikalı Yarim (Lütfi Ömer Akad, 1968), which is famous with the line "Even love was not enough". In some films, although these obstacles are absent, sometimes some characters cannot be easily reunited because they do not make an effort for secure attachment. The stories of these characters who cannot meet and unite sustain mainstream and independent cinema in different ways in different periods due to its support for melodramatic narrative. Attachment problems or, in other words, different attachment models, became popular for Turkish cinema as "Issız Adam Syndrome" by Çağan Irmak's melodrama called IsSIz Adam (2008). But before the neoliberal era, Ilyas in Selvi Boylum Al Yazmalım (Atıf Yılmaz, 1977) is one of the most important examples of "Issız Adam"s in Turkish cinema. In the film mentioned above, Asya's relationship with Cemşit, which is implied as a secure attachment through the phrase "Love was labor" in the film, can be discussed in terms of the attachment model.

In this study, with also taking into account the therapeutic potential of cinema referring to Jodorowsky, who says "The world is ill. We need to make therapy pictures. If art is not a medicine for society, it's a poison." (Çubukçu, 2020), it is aimed to consider the concept of attachment, which is accepted as one of the psychological needs of humans, and what it has transformed into with the spirit of the time, through mainstream and independent Turkish films selected from different periods with the purposeful sampling method.

\section{THE ATTACHMENT PARADIGM AND CINEMA}

Cinema relates with psychology not only for analyzing film theory or understanding spectatorship but also to provide an opportunity to the field. The therapists have used the 


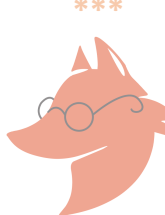

therapeutic potential of cinema for a long time. Watching films and dramas and using the representation in those narratives for therapy can be a choice in some cases. If the patient is suitable for film therapy, the therapist can choose to ask questions through the film hence can analyze the decisional pattern of the patient (Schulenberg, 2003). Also, without advising of an expert or therapist, art can act as a self-therapeutic. However, without an expert, the people who are not suitable for film therapy will also receive the messages of those films and probably miscode them.

As Duschinsky \& Reijman (2016, p. 398) state, attachment theory is one of the essential contemporary developmental paradigms. The paradigm owns its effect in somehow to filming. The founder of the attachment theory John Bowlby developed his arguments based on a collaboration in the 1950s with James and Joyce Robertson. They filmed young children separated from their parents by hospitalization.

Many studies in the field have followed the attachment theory of Bowlby and the attachment model of Ainsworth. Waters et al. (2015, p. xv) mention further studies and choose the word paradigm to explain the general perspective:

John Bowlby liked to refer to attachment theory as a new paradigm, a new way of understanding the infant's tie to primary caregivers. (...) Thus, the attachment paradigm refers to both BowlbyAinsworth attachment theory and to the community that shares and contributes to their perspective, as distinct from the psychoanalytic and learning theory perspectives.

Fraley \& Shaver (2000, p. 133) states, "Although attachment theory was originally designed to explain the emotional bond between infants and their caregivers, Bowlby (1979/1994) believed that attachment is an important component of human experience 'from the cradle to the grave' (p. 129)."

Hazan \& Shaver study this issue in several studies, Fraley \& Shaver's work summarize the findings of that studies. Hazan \& Shaver "conceptualized romantic love, or pair bonding, as an attachment process, one that follows the same sequence of formative steps and results in the same kinds of individual differences as infant-parent attachment." (Fraley \& Shaver, 2000, p. $133)$. In the study, Fraley \& Shaver (2000, p. 135) state the common elements and the patterns:

(...) both kinds of relationships involve periods of ventral-ventral contact, "baby talk," cooing, and sharing of interesting "discoveries" and experiences. Thus, the emotions and behaviors that characterize romantic relationships and infant-parent relationships share similar activating and terminating conditions and appear to exhibit the same latent dynamics (Shaver et al, 1988).

There are different approaches to insecure attachment. Hazan and Shaver classify insecure attachment as anxious and avoidant. Bartholomew and Horowitz analyze the insecure attachment depending on the perception about self and others; hence add the terms fearfulavoidance and dismissing-avoidance (Fraley \& Shaver, 2000, p. 142). 


\section{MEDINA}

\begin{tabular}{|c|c|c|}
\hline & \multicolumn{2}{|c|}{$\begin{array}{c}\text { MODEL OF SELF } \\
\text { (Dependence) }\end{array}$} \\
\hline & $\begin{array}{l}\text { Positive } \\
\text { (Low) }\end{array}$ & $\begin{array}{l}\text { Negative } \\
\text { (High) }\end{array}$ \\
\hline $\begin{array}{l}\text { Positive } \\
\text { (Low) }\end{array}$ & $\begin{array}{c}\text { CELL I } \\
\text { SECURE } \\
\text { Comfortable with } \\
\text { intimacy and autonomy }\end{array}$ & $\begin{array}{l}\text { CELL II } \\
\text { PREOCCUPIED } \\
\text { Preoccupied with } \\
\text { relationships }\end{array}$ \\
\hline (Avoidance) & CELL IV & CELL III \\
\hline $\begin{array}{c}\text { Negative } \\
\text { (High) }\end{array}$ & $\begin{array}{c}\text { DISMISSING } \\
\text { Dismissing of intimacy } \\
\text { Counter-dependent }\end{array}$ & $\begin{array}{c}\text { FEARFUL } \\
\text { Fearful of intimacy } \\
\text { Socially avoidant }\end{array}$ \\
\hline
\end{tabular}

Figure 1. Model of adult attachment (Bartholomew \& Horowitz, 1991, p. 227)

Levine \& Heller (2018, p. 47) define two determinants for the attachment model as the level of comfort or avoidance of intimacy with partner and anxiety and mind preoccupation with the relationship in their study. They design their schema showing the attachment style based on Two Attachment Dimensions Scales by Brennan, Clark, \& Shaver.

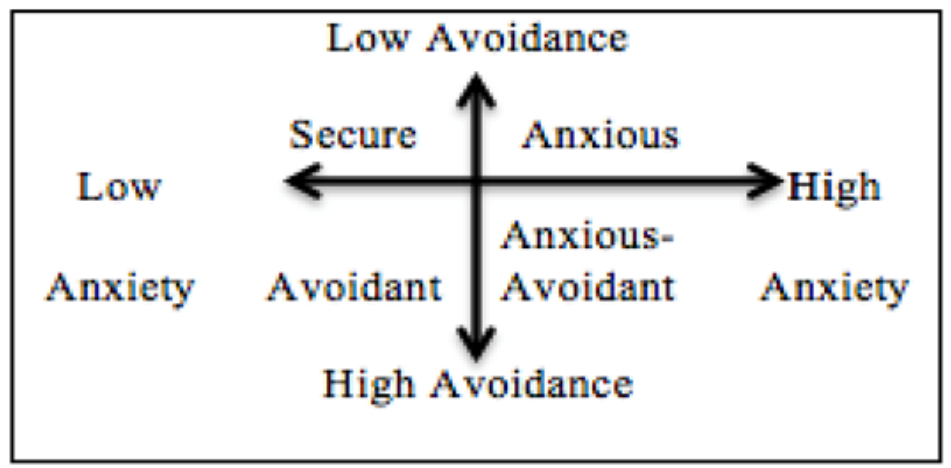

Figure 2. The schema showing the attachment style (Levine \& Heller, 2018, p. 47)

"Attachment refers to the affective bond between infant and caregiver. Its evaluation is based on a behavioral system regarded as universal, yet allowing for highly significant individual differences along a continuum from secure to insecure attachment." (Blum, 2004, p. 547). Moreover, the concept of attachment is dependent on the culture (Belsky, 2007, p. 10). Cozzarelli et al. (2003, p. 343) mention, "Bowlby (1969/1982) suggested, working models of attachment remain open to change in response to personal and interpersonal circumstances, we should be able to predict meaningful change in attachment style across time and across relationships."

By taking into account the attachment paradigm and both the manipulating and therapeutic potential of cinema, the films will be analyzed in the following section. 


\section{FILMS SELECTED AS SAMPLES AND ANALYSIS OF THE FILMS}

In this study, ten films were selected from a wide range of the period between 1965 and 2020 and analyzed to discuss the different attachment patterns and gender conventions. Even the production years of the films in the sample set spread a long time. Ten Turkish films in this study were selected with purposeful sampling, considering that the relationship and attachment problems/ways are at the center of the films' theme. For the purposeful sampling, the films were evaluated to achieve the diversity in the sample set according to their characters' attachment models, whether they are independent or mainstream, and the periods they were produced. The films Vesikalı Yarim (Lütfi Ömer Akad, 1968), Selvi Boylum Al Yazmalım (Atıf Yılmaz, 1977), Sevmek Zamanı (Metin Erksan, 1965), Issız Adam (Çağan Irmak, 2008), Kader (Zeki Demirkubuz, 2006), Biz Böyleyiz (Caner Özyurtlu, 2020) and Körleşme (Hacı Orman, 2020) are examples to discuss examples of avoidant, anxious, and anxious-avoidant attachment. The films Mucize (Mahsun Kırmızıgül, 2015) and Nadide Hayat (Çağan Irmak, 2015) are examples to question secure attachment from different perspectives. Gerçek Kesit: Manyak (Onur Ünlü, 2018) is chosen as an extreme example because it reveals the relationship between insecure attachment and the crisis of masculinity with violence. Sevmek Zamanı, Kader, Körleşme and Gerçek Kesit: Manyak can be considered as independent films, Vesikalı Yarim, Selvi Boylum Alyazmalım, Issız Adam, Biz Böyleyiz, Mucize and Nadide Hayat can be considered as popular films.

Vesikalı Yarim (Lütfi Ömer Akad, 1968), one of the cult films of Turkish cinema, is an important melodrama known with the line "Even love was not enough", which gave its name to this article. The film is about the impossible love between Halil, who represents the traditional values in the periphery, and Sabiha, who cannot be modernized but cannot find a place in the traditional patterns, who is stuck in the periphery of the center. Halil, who works in his father's grocery store, has an ordinary life. One evening, he meets Sabiha, who works at the pavilion he went to at the insistence of his friends. Sabiha and Halil fall in love with each other and start living together. Miscommunication prevails in their relationships, with which they broke up and reconciled more than once. Sabiha is afraid that the answer will be yes, so she cannot ask Halil whether Halil is married or not. In addition to being unable to discuss their real problems, they also harm each other physically and psychologically. When Sabiha finds out that Halil is married, she decides to leave. Halil stabs a person in a fight over Sabiha and goes to jail. Sabiha, but then tells her friend that she knows from his father's story that she can fight another woman, but that she cannot fight children, and that Halil will eventually return home. The day Halil comes out of jail, Sabiha resumes working in the pavilion to drive him away. When Halil comes out of jail, he stabs Sabiha. Sabiha but then does not complain about him and defends Halil by saying that eyewitnesses slandered Halil. When Halil returns home, he is greeted with great understanding by his wife, who has been deceived for a long time. Halil's wife prepares the bed for Halil, for whom he stretches his slippers, and asks Halil if he is hungry. At the end of the film, Sabiha looks at Halil, who returns to his father's greengrocer shop and takes care of his children, while Halil's father notices Sabiha and gets ahead of Halil. Thus, the law of the father protects the family. In the film, Halil's mother and wife represent traditional women; they are in blind allegiance. Sabiha and other women working in the pavilion are also victims of fate, not marginalized, but also not in the same conditions as traditional women. The discourse of the film does not marginalize women. It is possible to talk about a relationship in which Sabiha is avoidant- 


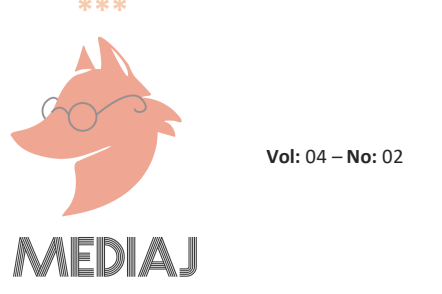

anxious, and Halil is anxious. The source of conflict between the characters is external. The film's discourse underlines the necessity of favorable conditions to reach a happy ending, in harmony with the famous line, "Even love was not enough. We would meet long ago".

Selvi Boylum Al Yazmalım (Atıf Yılmaz, 1977), one of the cult films, discusses the concept of love through Asya's relationships with ilyas and Cemşit. The truck driver ilyas has a sexual relationship with Dilek, the secretary at the company where he works. Illyas comes to the village where Asya is staying for work. Asya would marry someone she does not know. Asya and ilyas fall in love even though they do not know each other much. They speak with inner voices. "I held his hand as if his heart was in my hand" "If I hold her hand, will she come with me?" "Here, I am yours; take me away" lines will have a dramatic effect on both the reunion and the separation scenes. These lines will be repeated at the end of the film and in the final scene of the film IssIz Adam, the speech of inner voices, regardless of the lines, will take place as an intertextual reference to this cult film.

Asya and ilyas run away together from Asya's village, they do not marry officially, but they have a wedding. Their child, Samet, is born. Because ilyas is a trucker, he often takes to the road, leaving Asya alone with Samet. One day, ilyas, who sets off again, is complained by a colleague for helping another vehicle with Cemşit, whom he does not know yet. ilyas starts having problems at work. He is not fired, but he needs to leave his beloved truck and start working in the garage as a punishment. Dilek reminds that he should not rebel because he has a family and so responsibilities. Regular life, rather than often being on the road, and his responsibilities make ilyas very unhappy. When Asya is very saddened by ilyas's situation, she goes to talk to ilyas's boss with a friend of ilyas, without his knowledge and permission. Dilek, who still likes ilyas, tells this situation to ilyas. When Illyas goes to the boss's office, he sees Asya leaving the door, and Ilyas, unable to control his anger due to the implied insults he made about sending his wife to the boss, hits Asya. Ilyas, who has not come home for months, cheated on Asya with Dilek. After the colleague of ilyas tells Asya that he cheats on him, Asya goes to Dilek's house, looks inside the window, sees the two of them together, runs away from ilyas and leaves her home.

Dilek tells ilyas to return home. Dilek, who was the bad woman representation until that time, also emphasizes the unity of the family. Cemşit, whom he coincidentally encountered with Asya, takes care of Asya, who has nowhere to go. Cemşit's child and wife had passed away. Asya, who stayed with Cemşit for a while, returns to make peace with ilyas, but when she finds out that ilyas has gone with Dilek again, she returns to Cemşit. Cemşit supports Asya, helps her to find a job, waits for her to love him, even though he knows she's still waiting for her husband. Finally, they have a friendship-based marriage. They have a formal wedding. Asya is upset that her previous marriage is not considered valid because it was not an official marriage and tries to make sense of why she was excited about this wedding. Samet knows his father as Cemşit, and calls Cemşit, father. One day, Cemşit, who saw ilyas who had an accident, brings him home without knowing that ilyas is the ex-husband of Asya. Even if he understands the situation, he does not react; Cemşit is discreet and helpful. Although he does not verbally say that he will respect Asya's decision, it is seen that, in fact, he understands the situation and will act mature. ilyas, who visited his son as his ilyas uncle without saying he is his birth father several times, finally kidnaps Samet, and when Samet cries, ilyas has to stop. Asya took a shortcut and got in 


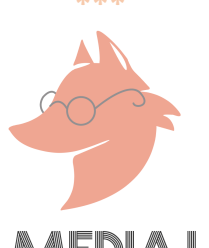

front of them, and Cemşit followed them. When Samet ran to Cemşit saying "father", Asya questions what love is. The discourse of the film overlaps with the line of Asya, "love was labor, goodness, friendship, and trust". However, still hearing the lines before escaping in their inner voices also shows that the attraction between them continues. When examined due to attachment models, it is seen that ilyas was tied in an avoidant manner, Asya was waiting for his return but did not follow him when she learned that he was cheated on her, that she was attached securely; it can be thought that Cemşit was securely attached, too. Asya's decision seems to be based on whom Samet calls father rather than who she is happy with, reminiscent of maternity determination in the Caucasus Chalk Circle. For this reason, it is also controversial that an ideal attachment can be mentioned. When considered in terms of women's representations, although Dilek is the woman with whom ilyas was before Asya, Dilek is not indeed his lover. Asya, on the other hand, was represented as a chaste woman to marry and bond. ilyas is at peace with Dilek, not with Asya he idealizes. This situation suggests that if there were no external conflicts; indeed, ilyas's relationship with Dilek could be considered as a secure attachment. It suggests that a relationship with Cemşit or someone else can be regarded as a secure attachment in conditions where Asya is more active and prioritizes herself in her preference. While the film demolishes the cliché by showing the woman maintaining the relationship with the understanding and thoughtful man who may be her friend instead of the handsome boy, it built another stereotype that the woman owes herself to the man who is laboring for her.

One of the cult films of Turkish cinema, Sevmek Zamanı (Time to Love, Metin Erksan, 1965) is also an example of the independent films of early Turkish cinema. Halil works as a painter with his master Mustafa on the island. Halil fell in love with the picture of a woman hung on the wall of one of the empty mansions he painted. He enters the mansion every day and watches the painting. One day, Meral, the daughter of the mansion owner, comes to the mansion with her two friends and sees Halil watching her painting. Believing that Halil is in love with her, Meral responds to this love. However, Halil says that he is not in love with Meral, but he is in love with her painting. For a while, he avoided Meral's attention. His relationship with the picture is both love for the image and an unchangeable one, the ideal concept referencing Plato's works. Halil knows that he would not be hurt in this relationship, but his relationship with Meral might bring him pain; he could be abandoned. In Meral's relationship with her ex-boyfriend Başar, it is possible to say that Başar, who does not accept the separation and attacks Halil, is anxious. After a while, Halil responds to Meral's interest. Meral's father, who does not openly oppose this relationship, talks about class differences and external obstacles between them. When Halil decides to leave Meral, Meral says that this decision means her death, but she will not object. In this relationship, it is possible to say that Halil's attachment model is the avoidant manner and Meral's attachment model is secure.

After separating from Halil, Meral decides to marry Başar but escapes from her wedding in a wedding dress. Meral goes back to Halil, traveling by boat with Meral's picture and a model mannequin wearing a wedding dress. Halil has escaped from reality to the ideal, but when Meral arrives, she throws the portrait and the mannequin, which are the symbolism of the ideal, into the sea. Although the characters' reunion at this point, the film ends with a dramatic ending when Başar shoots Halil and Meral. In the film, Meral is represented as an ideal woman, except 


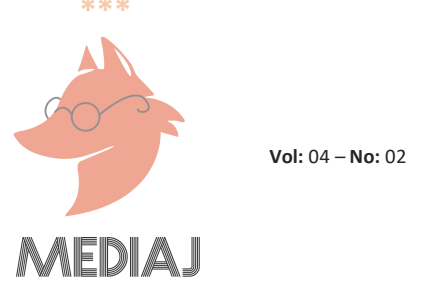

that she decided to marry Başar and then abandoned her. Meral is positioned according to Halil's needs in the relationship. The conflict between the characters is first internal and then external. The film reproduces myths such as love to the image/semblance in Eastern literature, impossible love, Saudade, inability to the reunion, dramatic ending, and the discourse of unsafe attachment.

The film IssIz Adam (Çağan Irmak, 2008), through its character of Alper, gave its name to the Issız Adam syndrome, which is used in popular culture to describe the avoidantly attached people. Alper is a character who is stuck between the provinces and the city he came to with the modernization crisis and could not solve his problems with his mother or his attachment problems. The film discusses the attachment paradigm through Alper and Ada's relationship. In line with the avoidant attachment in the film, Alper pursues Ada, whom Alper idealized initially until he persuades Ada of the relationship. Ada, was distant to Alper at the beginning, as she had experienced similar relationship patterns, and she also verbally stated this. When Ada is later convinced, she quickly gets involved in Alper's space. The film tells about the relationship between them. Alper has also established a distant relationship with his mother, and he is dominant in his relationships with the people around him and the people he has sexual relations with. Alper's hedonism, addiction to control, and the need for distance make him think that he has a narcissistic personality. Alper's cooking for Ada is a romantic sign of a relationship. While Alper invites and includes Ada in his own space, he cannot deal with this closeness on the other hand. When Ada meets Alper's mother and gets along well, it becomes an unbearable intimacy for Alper and he says he wants to leave while everything seems to be fine.

Ada says that he has done wrong and that he will regret it instead of talking to Alper and trying to convince her. When they meet years later, they continue a daily conversation like in the film Selvi Boylum Al Yazmalım, as well as a dialogue that tells them that they still love each other from their inner voices. Alper realized that he had made a mistake, but when he left, he could not find Ada and carried the buckle of Ada in his pocket for years. Instead of trying to communicate with Alper, Ada went to Alper's mother and dreamed of being happy with her in the house where Alper grew up. Later, when she returned, she married another person, moved to England, and gave birth to a child. Her inner voice tells that she imagines Alper instead of the person she is still married to. In the film, the conflict of people is internal, on the other hand, it is possible to think that these internal conflicts coincide with the dominant discourse of the neoliberal paradigm, individualism, and hedonism, in line with the spirit of the time. The reason why Ada married someone else while still loving Alper is not explained in the movie, but it is possible to think that this marriage and being a mother are compatible with gender conventions. The film discourse represents the miscommunication between the characters, the effortlessness, the lack of labor, the inability to be connected, and the escape instead of struggling to solve problems as a manifestation of melodramatic love.

The film Kader (Fate, Zeki Demirkubuz, 2006) narrates Bekir's obsessive love for Uğur. Bekir is in love with Uğur; Uğur is also in love with a sociopath nicknamed Zagor. After being released from prison, Zagor kills Uğur's mother's lover Cevat in a fight, and Zagor and Uğur escape. With this situation, the life of Uğur's young mother, Uğur's paralyzed father and younger brother, who lives under Cevat's protection, deteriorates. For Bekir, who is obsessed with Uğur, this situation 


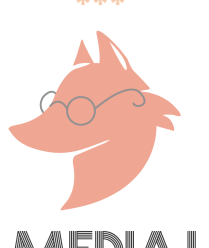

will be salvation. Bekir marries a girl his family finds. But when his wife was pregnant, seeing on the news that Zagor killed two police officers in Izmir and was caught, it would be an opportunity to reach Uğur. Bekir leaves his family, and Bekir becomes both the protection and the trouble of Uğur, who started working in the pavilions. The film continues with Bekir returning home many times and returning to Uğur back each time while harming each other and themselves psychologically and physically. The film is similar to Vesikalı Yarim; on the other hand, there is no obvious romantic relationship between Uğur and Bekir. Nevertheless, from the dialogues between them or the details such as Uğur's hanging the photo taken with Bekir on his wall, it is possible to think Uğur is avoidant, Bekir is anxiously attached, and there may be a meaningful relationship between them in another reality where Uğur can choose Bekir instead of Zagor, who turns her life into hell. Unlike Sabiha's representation in Vesikalı Yarim, Uğur is represented in misery. Bekir's wife also accepts Bekir every time, but unlike Halil's wife in Vesikalı Yarim, it is shown that he cries once in this film, and this time he is warned by his mother-in-law that he should not cry. It is learned from Bekir's conversation with his father that Bekir sank his father's shop, unlike Halil, who went back to his father's grocery in Vesikalı Yarim. Besides, despite all the selfishness and irresponsibility of Bekir, it is understood that the family always forgives him. The film realistically represents the toxic state of love that has become obsessed with discourse. The conflicts of characters with each other and with themselves arise from external conditions such as belonging to the lower socio-economic group as well as internal conflicts that lead them to destructive and damaging relationships for themselves.

The film Biz Böyleyiz (We are like this, Caner Özyurtlu, 2020) focuses on the situation of the relation between Emre and Gökçe. Also, it makes it possible to think about different relationship models through the relationships between Gökçe and his girlfriend Beril; Efsun, her husband Candaş, and Candaş's ex-girlfriend Meltem; and Dolunay and Mesut. Emre and Gökçe are two immature best friends who constantly play games with each other but cannot attach securely, love each other by hurting each other, just like in the film Jeux d'enfants (Love Me If You Dare, Yann Samuell, 2003). The stories continue along the axis of their efforts not to be lovers and to establish relationships with others, under the influence of Gökçe's grandmother's suggestion of "do not fall in love with your best friend" years ago. It is possible to say that the relation between Gökçe and Emre is an anxious-avoidant attachment. It is said that Gökçe and Beril had a secure attachment until the time they met Emre, that Beril noticed the strange relationship between them when Gökçe saw Emre, and that Beril decided to leave healthily, although she delayed it for a while due to the Gökçe's zig zags. The character to be represented as a figure that interferes with the main couple in the classical melodrama narrative, Beril, is shown as a rational, understanding, loving but also self-respecting character in this story. There is also a side story about Efsun, his wife Candaş, and Candaş's ex-girlfriend. Efsun sees herself as a securely attached person. She even gets angry with her friend Dolunay, who criticizes Efsun's husband's staying with his ex-girlfriend, and Efsun tells her that she is worried. Unlike everyone else, Efsun does not see her husband cheating on her. Candaş cheats on his wife with his ex-girlfriend. While the Dolunay character is represented as an anxiously attached and dominant spouse, Mesut is represented as a person acting in line with his wife's wishes. Representations of men and women in relationships differ and thus do not reproduce gender conventions from a single point of view. Although the clashes between the characters seem to be internal, as in the movie Issiz Adam, in this movie too, the lack of communication, effortlessness, running away, and inability to connect 


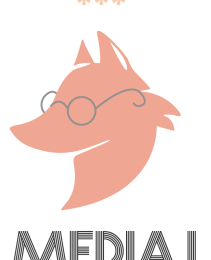

instead of struggling to solve the problems by saying, "We are like this" represents as a manifestation of the love between Gökçe and Emre.

Körleşme (Blindness, Hacı Orman, 2020) focuses on the relationship between the characters of Sinan and Nilgün, but as a side story, it makes it possible to discuss different relationship models with former spouses Varlık and Zuhal, and Zuhal and her new lover. Sinan is a blind poet. Although he lost his sense of sight when he was three years old, he is a witty person at peace with his blindness. There seems to be an ideal, harmonious, trusting relationship between Sinan and his wife, Nilgün. Sinan's wife, Nilgün, asks Sinan to see him and persuades him to undergo surgery. With the successful surgery, Sinan begins to see vaguely, but after a while, strange harmony chaos emerges. Nilgün believes that the chaos experienced is related to habits remaining from blindness and increases the pressure on Sinan to adapt to the world of vision. This tension leads to a tragic showdown in which they question each other's personalities. In this very process, the doctor explains that if there is no second surgery, Sinan will be blind as before. With the new situation, Sinan can be seen as anxious by avoiding Nilgün's attention and using ways such as following because he thinks that she is cheating on himself; thus, he behaves in an anxious-avoidant attachment model. In this case, only their own feelings are not decisive. Varlık, who is a friend of the same literary circle, who is also a mentor for Sinan, imposes the idea that women want to rule men on Sinan. Varol is a problematic person who has not been able to maintain his own relationship and continues to deal with him even though he is still in the same group of friends with his ex-wife, with who he is still in love and even inflicts violence on his ex-wife's lover on the pretext. His relationship with a woman who is younger than himself is more like the relationship between a narcissist and a fan rather than a romantic relationship. In particular, the inner conflicts of Sinan and Nilgün, the influence of the interventions, judgments, prejudices or existence of others, other than the persons in the relationship, regarding the anxious attachment of men to avoidant women, that is, external conflicts, are also visible in this relationship. As Sinan runs away, Nilgün enters Sinan's space; the persons cannot establish harmonious communication. Apart from that, Sinan learns that Nilgün is also using birth control pills without his knowledge. Nilgün's family is against Sinan, but this is not the only determinant in the birth control decision. Still, it becomes one of the turning points for Sinan. Blindness is a metaphor for a process in which Sinan and Nilgün began to fail to see each other's needs and sensitivities rather than Sinan's becoming blinded again. The film narrates that secure attachment is also dependent on conditions and that bonds will be damaged when the parties become blind to each other.

Mucize (Miracle, Mahsun Kırmızıgül, 2015) is a period film which tells about the healing power of love and a miracle through different relationships outside the center. The film narrates a teacher who goes to the Orient mission transforming the village that he went to without a school and healing Aziz, who is accepted to be crazy because he is disabled. The teacher honestly does not ask his wife for the money needed to build a school. Instead of talking to his wife directly, he pretends that he was kidnapped and asks for a ransom for his own life. Still, the urban woman is not marginalized, as can be seen at the end of the film. In the story, the men living in the village marry the women who first they see at the wedding, and their mothers liked for them by arranging, this episode is an element of comedy at the beginning. The man who says he wants the woman to marry to have beautiful teeth marries a woman whose teeth are ugly. The man 


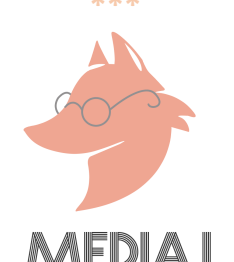

who says he wants the woman to marry to have beautiful eyes marries a cross-eyed woman. But in the following scenes, for example, the man who marries the cross-eyed woman talks about how much he loves his wife. This situation indicates that the happiness to be experienced in relationships is far beyond expectations. Aziz's father saves Mizgin's father's life. Mizgin's father also decides to marry his daughter, Aziz, whom he has not seen. Unlike other caricatured women, Mizgin is perfectly beautiful. Aziz continues to improve at school. Although Aziz and Mizgin try to be happy together, some people in the village bully them. They run away from the town, live with the teacher, and return with the teacher years later. Aziz had healed Mizgin and two children. He replies as "No, I fell in love with my wife", when asked by his father, "Have you had surgery?" In addition to the secure attachment as discourse, the film also emphasizes the healing power of love.

The film Nadide Hayat (Precious Life, Çağan Irmak, 2015) can be an example of secure attachment; it focuses on the transformation of the female character and her journey as a hero. Nadide Gürbüz left university for the will of her husband to marry and became a housewife and did nothing for herself until her husband died and her children grew up and started their own lives. Nadide, who attended many courses to recover her life after her husband died, cannot be happy here. However, thanks to the student amnesty she learned from the news one day, she returned to the school she left off years ago. Since Nadide is thought to be a Professor because of her age, the funny events that take place start his journey. Later, with her struggle during her journey on the research ship to save the Caretta Caretta's, she gains the respect of her schoolmates who initially excluded her, the university professor who could not internalize the feminist discourse, and the ship's captain Yusuf, whom she could not agree on since the first day of school, and her life changes. The tension between Nadide and Yusuf in the film turns into a part of the romantic narrative.

Nadide's self-realization, living what is expected of herself as a woman who is a grandmother, choosing to be the hero of her own story instead of being in line with gender conventions and social norms, are important for female representation. In the film, Nadide is initially responsible for cooking on board, while at the end of the film, Nadide, who made Yusuf meals, is represented as the person who deals with money. On the other hand, Yusuf's courage to get rid of his own fears and start a new relationship by being influenced by Nadide's courage to be herself, and when Nadide hesitates to anticipate external conflicts such as social pressure, he tries to persuade him in an anxious and non-insistent manner, even if he hesitates instead of running away, these are all important for the secure attachment narrative. The film also questions relationships through the relationship models of different couples. It includes the relationship of a young lesbian as well as a young woman who chooses a happy relationship with another friend instead of a partner who humiliates, restricts, and devaluates herself. It is the effort to save the lives of other creatures that keep the heroes together in the film. Nadide makes one think of Caretta Caretta's, which is one of the endangered species for the film Nadide (Precious) Hayat, in the sense of "Precious Life" as well as the name of the hero. As a discourse, the film underlines the links of a safe relationship with self-realization and supporting the self-realization of the partner, while also emphasizing the values such as seeking the meaning of the world outside of itself, adding value to the world, transforming it, and protecting life for all living things. 


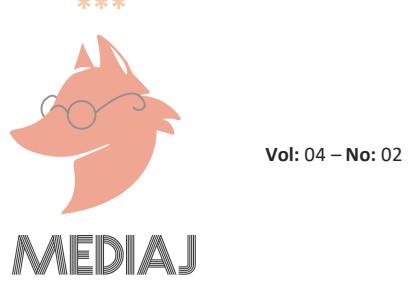

In the film Gerçek Kesit: Manyak (Reality: Maniac, Onur Ünlü, 2018), Rıza killed Serpil as a result of thinking himself to be Serpil's lover. There is no real relationship between the two that Serpil is aware of it. The problematic relationship here is Rıza's relationship with his mother, himself, and reality. The film starts with a man throwing the body of a killed woman in the garbage, which the cleaner Rıza found in it. Throughout the film, we see what made Rıza maniac and how. The crisis of masculinity, the problematic and unbreakable bond with the mother of the undeveloped boy, the manhood that cannot separate his personality from his mother, Riza's mother's psychological violence against Rıza, and the physical violence that Serpil inflicts on her child but which we can expect from Rıza's mother, and symbolic militarism violence-based society drive Riza maniac. The film tells the story of being in love with the image in a realistic way through its spooky side, rather than a romance shown in Sevmek Zamanı. Rıza interprets daily communication with Serpil as a romantic relationship, then begins to act like a spy, stalk, and harass her. At the end of the film, Riza throws Serpil, whom he killed, like the killer at the beginning of the film, into the garbage. The film is essential in terms of showing Persistent Stalking. Persistent Stalking is defined in law no 6284, which is the law enacted within the scope of the Istanbul Convention, and how the misunderstood romance manifests in the context of gender conventions, harassment, and violence. Serpil's boss, who proposed to Serpil even though he was married, is important for how attachment theories should be analyzed from the perspective of polygamy. This question may be the subject of a future study.

\section{CONCLUSION}

Since we think and feel through films that are mass media products and works of art, analyzing films' discourses is significant whether they show in what form society transforms into or in what form society is wanted to be transformed into. In both cases, the films affect, change, create or raise awareness, and function to understand the transformation. So the study does not really focus on the films' intentions; either they voluntarily produce their discourse or accidentally/subconsciously.

This study examines the discourses of the sample films on the attachment paradigm and gender perception related to that paradigm. Most of the films analyzed represent insecure attachment patterns. In some cases, they only try to mirror reality, but in some cases, they reproduce the discourse about individualism, alienation, lack of labor to repair the bonds. Gender representations are different in the films, but most of the films still reproduce stereotypes about gender. To be a woman is indeed linked with being a mother and a part of a family. In Körleşme, abortion takes place as a part of the separation. Most of the characters also can be analyzed due to their relations with their parents or children.

We can analyze the films due to their characters' attachment model or films' discourse about gender stereotypes.

In Vesikalı Yarim and Biz Böyleyiz, couples are anxious-avoidant; when one is ready for the attachment, the other escapes; however, there is an external reason in Vesikalı Yarim. Still, in Biz Böyleyiz, the only external motivation is the advice of Gökçe's grandmother for not falling in love with a friend. In Issız Adam, Selvi Boylum Al Yazmalım, Sevmek Zamanı and later on 


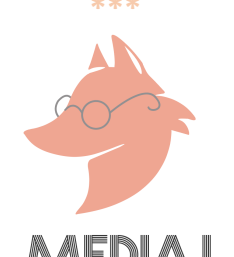

Körleşme, leading man characters are avoidant; in Kader leading man character is anxious. Başar in Sevmek Zamanı is also represented as an anxious character. The situation about Cemşit is a little bit different, he gets anxious to lose his family, but he can control his emotions not to discomfort Asya. Yusuf Kaptan in Nadide Hayat is the only leading man who exemplifies a real secure attachment.

Leading woman characters are shown more securely attached. In Sevmek Zamanı, Selvi Boylum Al Yazmalım, Mucize and Nadide Hayat woman characters know or learn secure attachment. In Körleşme, after losing the secure attachment, the woman character Nilgün probably decides to leave.

Society and characters in Vesikalı Yarim, Selvi Boylum Al Yazmalım, Kader, Mucize, Issız Adam and Körleşme underline the importance of family and gender codes are supposed to be suitable for the family. In Biz Böyleyiz and Nadide Hayat, gender codes and ideal family are discussed. The discourses of the two films are not, in fact, against family, but they offer more realistic and supportive families and gender codes.

The film Gerçek Kesit: Manyak shows the masculinity crisis in society and the roots of violence against women and unsecured bonds that start in family and society.

We can also analyze the films with pairs. For example Vesikalı Yarim and Kader; Selvi Boylum Al Yazmalım and Issız Adam; Biz Böyleyiz and Körleşme can be related with their story according to their obstacles. However, the narrations and discourses differ in the films.

For example, in the films Vesikalı Yarim and Kader, obstacles come first from society. Leading men married to women their families find suitable for them; they really do not like their wives. Instead, the women they desire are jezebels who already or after that going to work in the pavilions. But positions and representations of Sabiha in Vesikalı Yarim and Uğur in Kader are different. Sabiha is represented in a melodramatic narrative as a star, but Uğur is portrayed more realistically in a tragedy. In Vesikalı Yarim, Halil returns to his family by giving up his love; hence, the film ends as a sad love story. Kader has no simple love story as it is found in Vesikalı Yarim. Uğur is avoidant, Bekir is anxiously attached. There may be a meaningful relationship between them in another reality where Uğur can choose Bekir instead of Zagor, who turns her life into hell. Bekir's wife also accepts Bekir every time, but unlike Halil's wife in Vesikalı Yarim, it is shown that he cries once in this film, and this time he is warned by his mother-in-law that he should not cry. The film realistically represents the toxic state of love that has become obsessed with discourse.

Biz Böyleyiz and Körleşme narrate the relations between the main characters and the friend groups, so films show many different types of relationships. But also, these friend groups in the stories do not supply support for healing the relations; instead, they disturb them or confuse the people about their relations. Not only the bonds between the couples but also the bonds between the friends are problematical.

Issız Adam is selected because, as mentioned before, through its character of Alper, gave its 


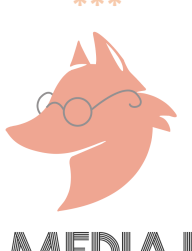

name to the Issiz Adam syndrome, which is used in popular culture to describe the avoidantly attached people. Ada and Alper's conflict is rooted in internal disputes in the film. Still, it is possible to think that these internal conflicts coincide with the dominant discourse of the neoliberal paradigm, individualism, and hedonism, in line with the spirit of the time. Selvi Boylum Al Yazmalım and Issız Adam share some similar codes for the main lovers' relationships. The films discourse represent the miscommunication between the lovers, the lack of labor, the inability to be connected, and the escape instead of struggling to solve problems as a manifestation of melodramatic love.

Selvi Boylum Al Yazmalım demolishes a cliché but reconstructs another one. The woman in the film is deserved by the Achates, and the woman's desire is underestimated for the good of motherhood and family. Hence the film's discourse is coherent with the family institution.

When the films Sevmek Zamanı and Gerçek Kesit: Manyak are analyzed parallel to each other, some romantic codes in one film, Sevmek Zamanı, could be terrifying in the other film, Gerçek Kesit: Manyak and in fact in reality. Stalking both physically and digitally is becoming an important issue for women and another type of violence in everyday life.

In Mucize, the film narrates the healing power of love; on the other hand, it also reproduces a discourse against a woman's right to choose her partner. Arranged marriage or giving one's daughter in marriage to are represented normal and in a romantic way.

Moreover, Körleşme and Mucize can also be analyzed in pairs due to their discourses on disability and the positions of the female characters in the films. In both films, woman characters, wives of disabled male characters decide and try to help the healing of their partners. The miracle happens in Mucize (Miracle). Still, in Körleşme (Blindness), the man's blindness repeats physically and metaphorically while his wife also gets blind metaphorically to the problems her husband has to face. The film narrates that secure attachment is also dependent on conditions and that bonds will be damaged when the parties become blind to each other.

The film Nadide Hayat demolishes all the cliche about gender and mentions the relationship between the secure attachment with self-realization journey and supporting the self-realization journey of the partner. It also emphasizes the values such as seeking the meaning of the world outside of itself, adding value to the world, changing the world, and healing life for all living things. It can rate as a positive model for its discourse.

Unlike Mucize and Nadide Hayat, films offer a dilemma between a peaceful life and desireful love. Love hurts, or real lovers cannot come together to all sample films. Even in Selvi Boylum Al Yazmalım, accepted love is apart from sexual attraction; the cost of being in a relationship with a reliable man is giving up being in a relationship with the desired man.

As stated before, if we consider cinema as a perverted art, as a part of the culture industry that manipulates us for the good of the hegemonic ideology, neoliberal paradigm, it is acceptable that we have no expectations from it. But, if we see the therapeutic potential of cinema, we can hope cinema can help us to understand healing ourselves and relations with self and the other. 


\section{MEIDIAJ}

It can help us to understand healing ourselves is not apart from healing the other, our world, and our self-realization journey. We can understand love as a word is not enough, and we need secure attachment patterns, gender equality and labor to achieve that patterns.

\section{REFERENCES}

Avşar, Ş. \& Özyurtlu, C. (Producer), \& Özyurtlu, C. (Director). (2020). Biz Böyleyiz [Motion Picture]. Türkiye: Avşar Film \& AC Film.

Bartholomew, K., \& Horowitz, L. (1991). Attachment Styles Among Young Adults: A Test of a Four Category Model. Journal of Personality and Social Psychology, 61, 226-244.

Belsky, J. (2007). Attachment and cultural context, Ed. John Oates., Attachment Relationships: Quality of Care for Young Children. Early Childhood in Focus, 1. Milton Keynes, The Open University, 10.

Blum, H. P. (2004). Separation-individuation theory and attachment theory. Journal of the American Psychoanalytic Association, 2004 Spring, Vol. 52 (2), pp. 53553. 10.1177/00030651040520020501.

Botasi, L. \& Demirkubuz, Z. (Producer), \& Demirkubuz, Z. (Director). (2006). Kader [Motion Picture]. Türkiye \& Greece: Mavi Film.

Cozzarelli, C., Karafa, J. A, Collins, N. L., Tagler, M. J. (2003). Stability And Change In Adult Attachment Styles: Associations With Personal Vulnerabilities, Life Events, And Global Construals Of Self And Others, Journal of Social and Clinical Psychology, Vol. 22, No. 3, 2003, pp. 315-346

Çubukçu, C. (2020). Jodorowsky'den terapötik belgesel: "Psychomagic, A Healing Art" [Therapeutic documentary by Jodorowsky: "Psychomagic, A Healing Art"] https://bantmag.com/jodorowskyden-terapotik-belgesel-psychomagic-a-healingart/?fbclid=IwAR2Yvgi_1VLIuzTDIQiaZhgtMlvrOmw4qkXPGKCLXy3ukEIOjpr3RED0X6w

Duschinsky, R. \& Reijman, S. (2016). Filming disorganized attachment, Screen, Volume 57, Issue 4, Winter 2016, 397-413, https://doi.org/10.1093/screen/hjw042.

Erksan, M. (Producer), \& Erksan, M. (Director). (1965). Sevmek Zamanı [Motion Picture]. Türkiye: Troya Film.

Fiennes, S. (Producer) \& (Director). (2006). The pervert's guide to cinema [Motion Picture]. United Kingdom: Amoeba Film, Kasander Film Company, Lone Star Productions, Mischief Films 


\section{MEDINA}

Fraley, R. C., \& Shaver, P. R. (2000). Adult romantic attachment: theoretical developments, Emerging Controversies, And Unanswered Questions. Review of General Psychology, 4, 132154.

Gerbner, G., L. Gross, M. Jackson-Beeck, S. Jeffries-Fox, N. Signorielli (1976). Violence profile No.7: Trends in network television drama and viewer conceptions of social reality 19671975, The Annenberg School of Communications University of Pennsylvania, http://www.asc.upenn.edu/gerbner/archive.aspx?sectionID=155\&packagelD=621

Gruber, D.R. (2014) Mirror neurons in a group analysis "Hall of Mirrors": Translation as a Rhetorical Approach to Neurodisciplinary Writing, Technical CommunicationQuarterly, 23:3, 207-226, DOI: 10.1080/10572252.2013.816489

Gülce, E. \& Oğuz, M. (Producer), \& Irmak, Ç. (Director). (2008). Issız Adam [Motion Picture]. Türkiye: Most Production.

Gür, S. (Producer), \& Akad, L. Ö. (Director). (1968). Vesikalı Yarim [Motion Picture]. Türkiye: Seref Film.

Hall, S. (1997). Work of representation, Ed. Stuart Hall, Representation: cultural representations and signifying practices, Sage, 13-74.

Hansen, Miriam. (1994). Babel and babylon: spectatorship in American silent film, Harvard University Press, 1994. ProQuest Ebook Central, https://ebookcentral.proquest.com/lib/istanbul-ebooks/detail.action?doclD=3300189.

Hayward, S. (2001). Cinema studies the key concepts, London: Routledge.

Illouz, E. (2011). Soğuk yakınlıklar duygusal kapitalizmin şekillenmesi [Cold Intimacies. The Making of Emotional Capitalism] Tr. Özge Çağlar Aksoy. İstanbul: İletişim.

Istanbul Convention (2011). Council of Europe Convention on preventing and combating violence against women and domestic violence.

https://rm.coe.int/CoERMPublicCommonSearchServices/DisplayDCTMContent?documentld=0 90000168008482 e.

Levine, A. \& Heller, R. (2018). Bağlanma aşkı bulmanın ve korumanın bilimsel yolları [Attached: the new science of adult attachment and how it can help you find-and keep-love]. Tr. Ebrar Güldemler, Aganta.

Lewis, T. (2011). Lifestyle, General Editor: Michael Ryan, Edited by M. Keith Booker, The encyclopedia of literary and cultural theory, Volume III Cultural Theory Wiley-Blackwell, 11451148.

Marx, K. (1976). 1844 Elyazmaları, Ekonomi politik ve felsefe [1844 Manuscripts, Political Economy and Philosophy], Tr. Kenan Somer, Sol, 89-268. 
Munsterberg, H. (2001). Hugo Munsterberg on film: the photoplay: a psychological study and other writings, Ed. Allan Langdale, Taylor \& Francis Group, ProQuest Ebook Central, https://ebookcentral.proquest.com/lib/istanbul-ebooks/detail.action?doclD=1272905.

Okan, C. \& Savcl, T. (Producer), \& Irmak, Ç. (Director). (2015). Nadide Hayat [Motion Picture]. Türkiye: TAFF Pictures.

Osman, H. (Producer), \& Osman, H. (Director). (2020). Körleşme [Motion Picture]. Türkiye: Praksis Film.

Özgentürk, A. (Producer) \& Yılmaz, A. (Director). (1977). Selvi Boylum Al Yazmalım [Motion Picture]. Türkiye: Yeşilçam Film.

Rossignon, C. (Producer) \& Samuell, Y. (Director). (2003). Jeux d'enfants [Motion Picture]. France: Nord-Ouest Films.

Schulenberg (2003). Psychotherapy and movies: on using films in clinical practice, Journal of Contemporary Psychotherapy: On the Cutting Edge of Modern Developments in Psychotherapy. March 2003 33(1), 35-48.

Sedgwick, P. (2003). Representation, Ed. Peter Sedgwick \& Andrew Edgar, Key concepts in cultural theory, Routledge, 225-226.

Süngü, B. \& Özcan, B. (Producer), \& Ünlü, O. (Director). (2018). Gerçek Kesit: Manyak [Motion Picture]. Türkiye: Bir Film.

Tokat, M. (Producer), \& Kırmızıgül, M. (Director). (2015). Mucize [Motion Picture]. Türkiye: Boyut Film.

Waters, E., Bretherton, I. \& Vaughn, B. E. (2015) Preface (2015), Ed. Mary D. Salter Ainsworth, Mary C. Blehar, Everett Waters, \& Sally N. Wall, Patterns of attachment a psychological study of the strange situation, Routledge, $x$-xxxvi. 